\title{
ADVANCES IN THE USE OF STEM CELLS IN ORTHOPEDICS
}

Alexandre Fogaça Cristante', Douglas Kenji Narazaki ${ }^{1}$

\section{ABSTRACT}

Primordial cells or stem cells are multipotent undifferentiated cells with the capacity to originate any type of cell in the organism. They may have their origins in the blastocyst and thus are classified as embryonic, or tissues developed in fetuses, newborns or adults and thus are known as somatic stem cells. Bone marrow is one of the main locations for isolating primordial cells, and there are two lineages: hematopoietic and mesenchymal progenitor cells. There are several uses for these undifferentiated cells in orthopedics, going from cartilaginous lesions in osteoarthrosis, osteochondritis dissecans and patellar chondromalacia, to bone lesions like in pseudarthrosis or bone losses, or nerve lesions like in spinal cord trauma. Studying stem cells is probably the most promising field of study of all within medicine, and this is shortly going to revolutionize all medical specialties (both clinical and surgical) and thus provide solutions for diseases that today are difficult to deal with.

Keywords - Orthopedics/trends; Stem Cells; Cartilage; Pseudarthrosis

\section{INTRODUCTION}

Primordial cells or stem cells are multipotent undifferentiated cells with the capacity to proliferate and originate cells of any lineage, thereby forming any tissue in the organism.

Stem cells can be classified as embryonic stem cells, which are found in the internal cellular mass of the blastocyst (embryo), or as somatic or adult stem cells, which are found in tissues developed by the fetus or newborn, or in adults. The somatic type can be obtained from bone marrow, peripheral blood, umbilical cord, fetal liver, neural tissue or a variety of mesenchymal cells in adults, such the synovium, periosteum, muscle tissue or adipose tissue.

In the bone marrow, there are at least two populations of progenitor stem cells: hematopoietic progenitor cells and mesenchymal progenitor cells ${ }^{(1)}$.

Hematopoietic progenitor cells express a membrane glycoprotein that makes it possible to identify and quantify such cells: the CD34 antigen. Other cells that also express CD34 include endothelial cells, embryonic fibroblasts and some cells within the fetal and adult nerve tissue. On the other hand, mesenchymal progenitor cells do not present any known cell surface marker. They can also be found in several solid organs and are identified solely through cell culturing.

These two cell populations are present in bone marrow and, under normal conditions, only $0.1 \%$ of them circulate in the peripheral blood. This number may increase around 30 to 50-fold after administration of hematopoietic colony-stimulating factors, especially G-CSF (granulocyte colony-stimulating factor).

\section{OBJECTIVES}

The aim of this paper was to provide better understanding of the nature of stem cells and their importance in medicine as a whole and in orthopedics especially, by covering the subject from its history to the current research.

With advances in medicine, it is now possible to

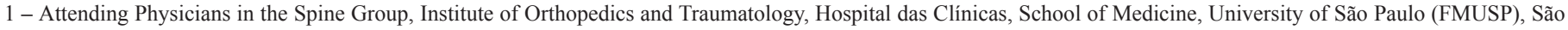
Paulo, Brazil.

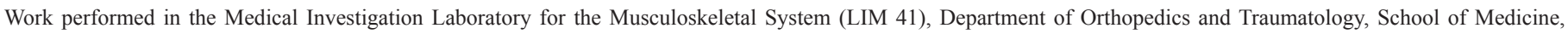
University of São Paulo.

Correspondence: Rua Dr. Ovídio Pires de Campos, 333 - Cerqueira Cesar - 054403-010 - São Paulo, SP, Brasil. E-mail: aacristante@uol.com.br Work received for publication: June 08, 2011; accepted for publication: June 28, 2011.

The authors declare that there was no conflict of interest in conducting this work 
extract, cultivate and reinfuse these progenitor cells for therapeutic purposes, to form various tissue types, including bone, liver, neural or adipose tissue ${ }^{(2)}$.

In orthopedics and traumatology, these cells can be used to form new tissues such as nerves, bone, cartilage and dense connective tissue (ligaments and tendons) (Figure 1).

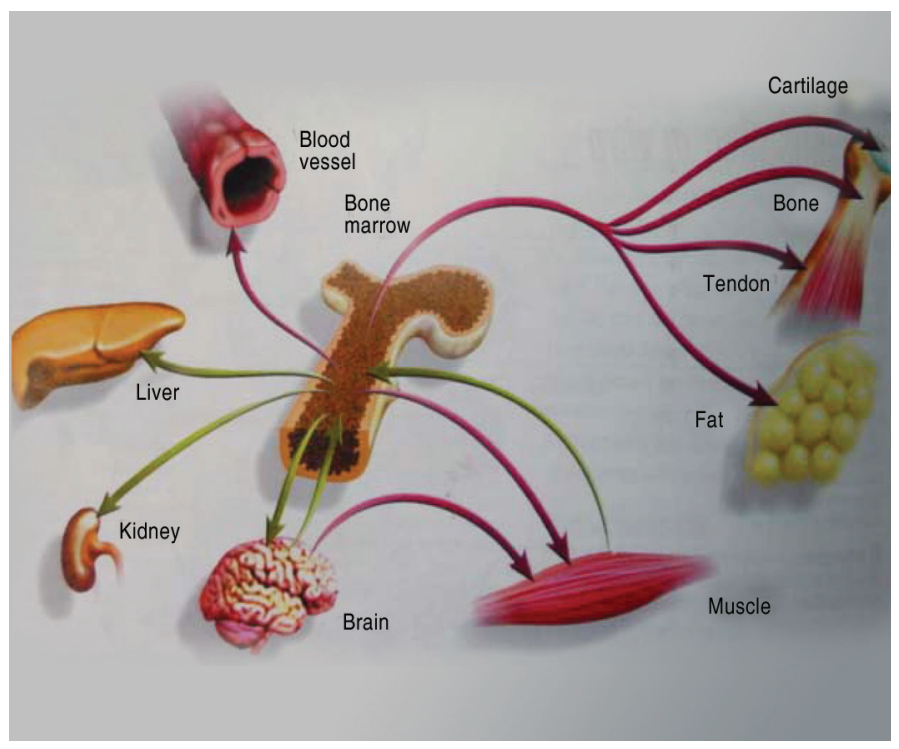

Figure 1 - Possible uses of multipotent cells for forming a variety of tissues.

\section{NERVE TISSUE}

The use of totipotent cells to form nerve tissue has importance in relation to degenerative diseases like Parkinson and in spinal cord injuries. In this section, we deal with the latter (Figure 2).

The first report of difficulties in treating patients with spinal cord injuries dates from 3000 BC, when it was believed that spinal cord injuries should not be treated. This description was made by Edwin Smith apud Barros Filho ${ }^{(3)}$.

During the First World War, $80 \%$ of the patients with spinal cord trauma died within the first two weeks after the trauma ${ }^{(3)}$.

During the Second World War, the concept of specialized spinal cord injury centers was developed in England. At these centers, with multidisciplinary teams, it was possible to dramatically reduce the mortality rate $^{(3)}$.

Spinal cord trauma used to be regarded as an untreatable disease. Until ten years ago, all that could be done was to stabilize the spine, treat infections and

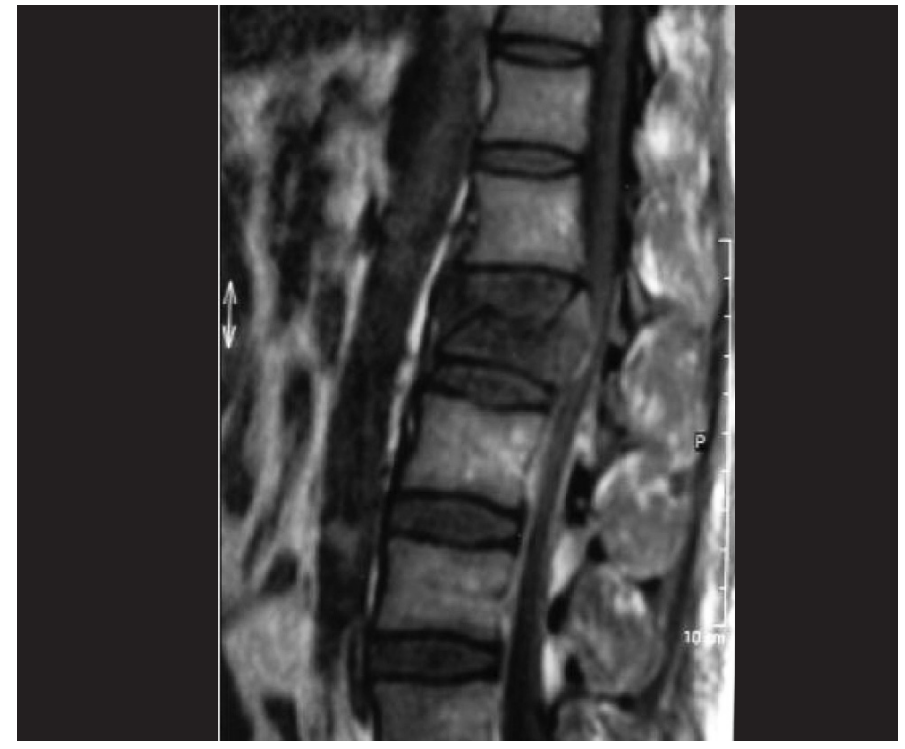

Figure 2 - Magnetic resonance imaging on lumbar spine, with T1 weighting, showing spinal cord compression resulting from a fragment of a vertebral body that was displaced posteriorly.

spasticity and prescribe physiotherapy ${ }^{(4,5)}$. However, research developed within this field has indicated that acute lesions of the spinal cord can be minimized through using drugs, provided that they are administered shortly after the trauma ${ }^{(6-10)}$.

At the start of this century, the first experiments on the physiopathology of spinal injuries were conducted $^{(11,12)}$. However, these studies were only taken up again later on in the past decade, by investigators who started to place value on time-dependent changes within the pathology of spinal cord injuries ${ }^{(13,14)}$.

The immense neurological deficits that result from spinal cord injuries come from the sum of two distinct events: the initial mechanical injury and the secondary endogenous lesion that is consequent to the initial injury ${ }^{(15-20)}$. This primary injury is produced directly by the trauma, and involves cell death and release of electrolytes, metabolites and enzymes. It is therefore a mechanical process that does not depend on cell control. Secondary lesions in the spinal cord involve complex biochemical changes that arise as a cascade of events comprising edema, inflammation, ischemia, reperfusion, growth factors, calcium metabolism and lipid peroxidase, and scientific investigative efforts have been concentrated on such events with the aim of controlling them ${ }^{(20-30)}$. In pharmacological terms, drugs that modulate the endogenous response to primary injuries are being progressively introduced with the aim of limiting the tissue damage and improving the 
potential for functional recovery among such patients. These drugs aim to interrupt the physiopathological mechanisms of secondary neuronal lesions ${ }^{(31-34)}$ (Figures 3 and 4).

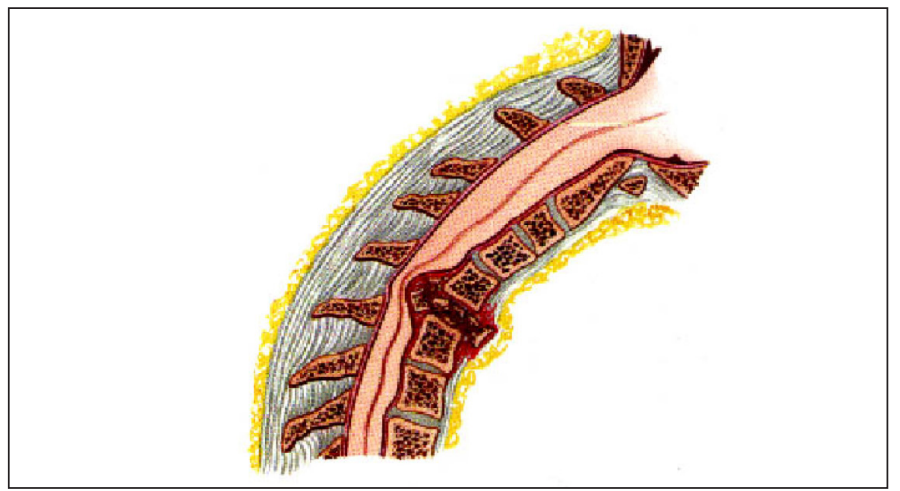

Figure 3 - Primary injury.

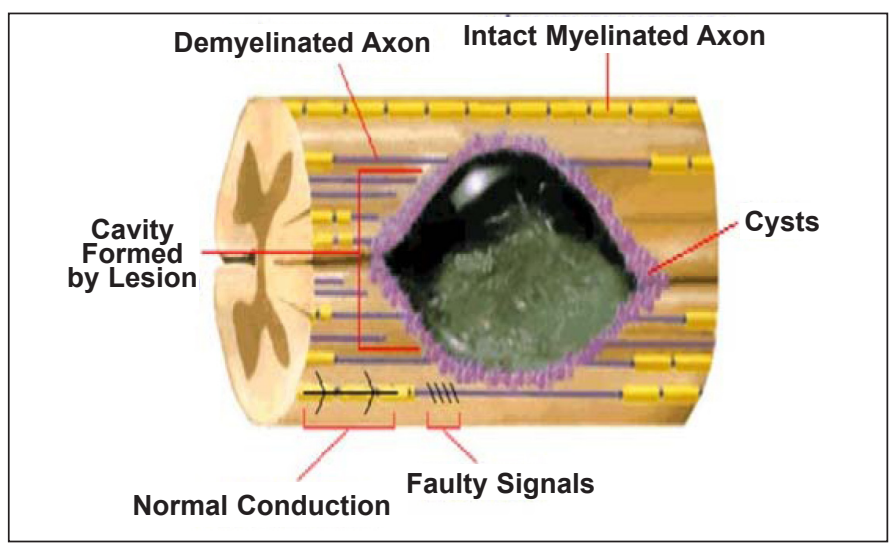

Figure 4 - Result after secondary lesion.

Clinical and scientific advances have indicated that acute lesions in the spinal cord can be manipulated by means of pharmacological therapy if used within a short space of time. Methylprednisolone administered within the first eight hours after the trauma was the first agent to produce a significant improvement in the recovery from spinal cord trauma in human beings ${ }^{(4,35-46)}$. Other drugs, like tirilazad ${ }^{(47-49)}$ and GM-1 ${ }^{(50-57)}$ have presented promising preliminary results. These advances may provide a great improvement in the quality of life of patients with spinal cord injuries, if they are brought into clinical practice. After injuries to the central nervous system, there is a period of deficit followed by a period of varying degrees of functional recovery. This recovery is due mainly to changes to the uninjured circuits, but the exact process involved in the recovery remains incompletely understood.
The ideal treatment for spinal cord injuries would be one that not only diminished the lesion but also stimulated the repair process. Contrary to the concepts of ten years ago, it has now been proven that neurons outside of the central nervous system, in the immature spinal cord and in special culture media may regenerate ${ }^{(58)}$.

Lines of research involving neurotransmitter use, fetal cell transplantation, undifferentiated cell transplantation, electrode implantation and use of remyelination-promoting substances have now been developed, but they have not yet presented definitive results.

Over the last ten years, use of stem cells in treatments for spinal cord injuries has been described in several experimental studies, with beneficial effects. The way in which these cells may act in repairing lesions of the nervous system is still a matter of controversy, but it certainly involves phenomena like functional reconstruction of neuronal circuits, with reestablishment of synapses or interconnections with host cells; production of neurochemical substances like neurotransmitters, growth factors and antibodies; and remyelination of undamaged axons that stopped producing electrical impulses because they were demyelinated.

Thus, at the Institute of Orthopedics and Traumatology, Hospital das Clínicas, School of Medicine of the University of São Paulo, a clinical trial was conducted to assess the effect of infusion of autogenous undifferentiated progenitor cells for treating patients with chronic spinal cord lesions ${ }^{(59)}$.

Thirty-nine patients who had presented traumatic spinal cord injury with a complete deficit for at least two years were selected. All of them followed a protocol to obtain their informed consent. The following were then performed: hemogram, coagulogram, magnetic resonance imaging on the spine and somatosensory evoked potential. None of the 39 patients presented any registered transmission of impulses to the cerebral cortex after stimulation of the lower limbs.

To obtain progenitor cells from the patients' peripheral blood, they were administered G-CSF. Five days later, stem cells were collected from the patients by means of an apheresis technique, using a continuous-flow cell separator. Through this, we obtained $2.5 \times 10^{6} \mathrm{CD} 34+$ cells per kilogram of patient weight, which were cryopreserved. Following this, these cells 
were cultured in a medium appropriate for developing cells of neuronal lineage.

These cells were infused by means of arterial angiography, which irrigated the lesion site and perfused the anterior spinal artery. We used dimethyl sulfoxide as the vehicle (Figure 5).

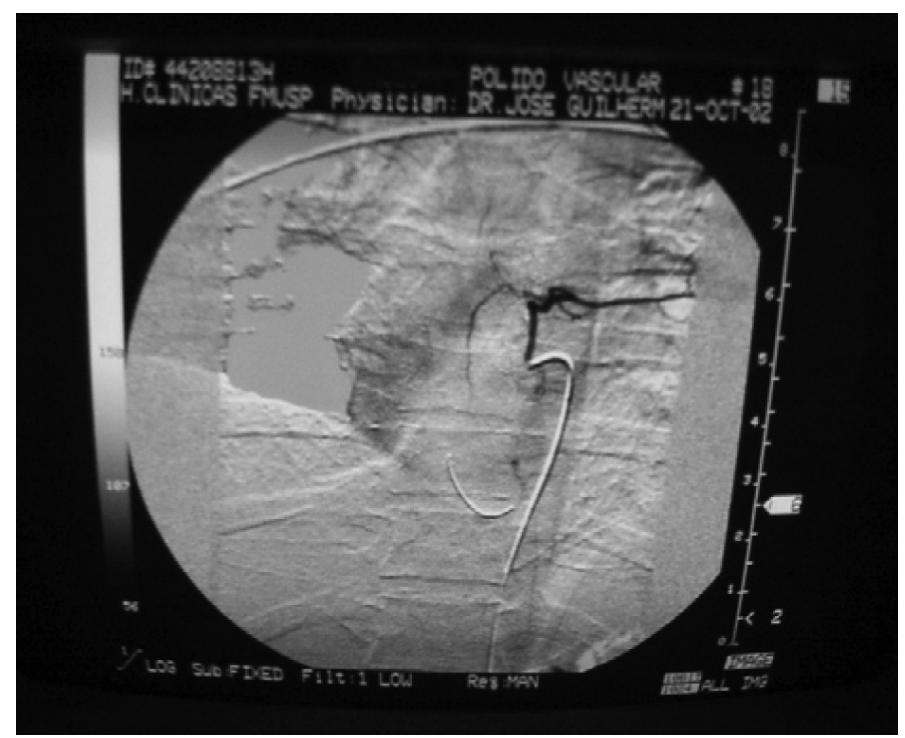

Figure 5 - Spinal cord angiography at the lesion site, showing perfusion of the anterior spine.

The patients were then followed up clinically, by means of somatosensory evoked potential and urodynamics.

The final result was that transmission of impulses in the cerebral cortex or improvement in the latency time for obtaining a cortical response after stimulation of the upper and lower limbs was registered in 26 patients. However, the sensory conduction took longer, with greater latency than in normal individuals (Figures 6 and 7).

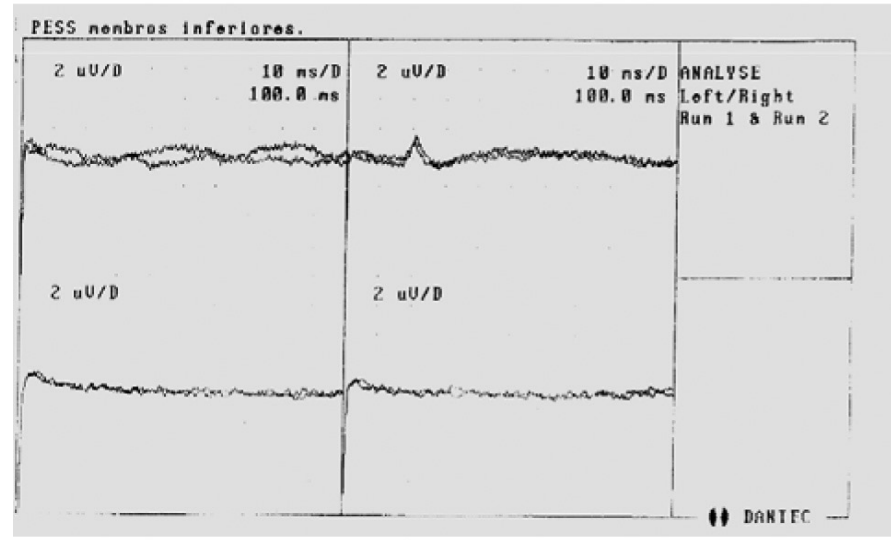

Figure 6 - Pre-infusion somatosensory evoked potential.

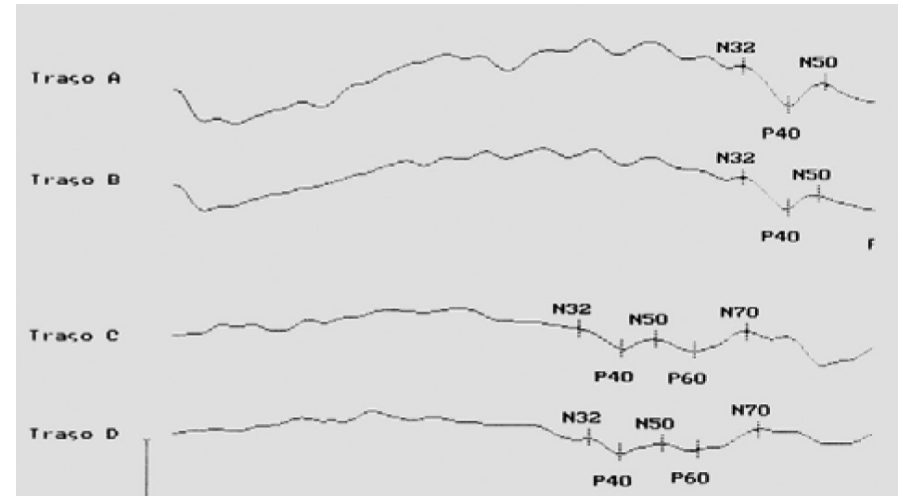

Figura 7 - Post-infusion somatosensory evoked potential.

Despite this response, the patients did not achieve any motor gains, clinically. Some showed nonspecific sensory improvement in the lower limbs. The complications observed with this therapeutic method included one case of pneumothorax consequent to passage of the double-lumen catheter to collect stem cells, and three cases of allergy to the contrast medium used in the arteriography ${ }^{(59)}$.

\section{CARTILAGINOUS TISSUE}

The primordial cells have also been studied in relation to formation of joint cartilage. Diseases like traumatic chondral lesions, osteochondritis dissecans, patellar chondromalacia and osteoarthrosis are therapeutic targets for these cells ${ }^{(58)}$.

When traumatic chondral lesions of the ankle and knee are small and in areas of low mechanical stress, they are usually treated conservatively, including restrictions on bearing the body weight, use of analgesics and anti-inflammatory drugs, and physiotherapy (Figure 8). When these lesions are extensive, they can be treated by means of perforation, autologous or homologous osteochondral grafts, replacement arthroplasty (partial or total prostheses) and arthrodesis.

Osteochondritis dissecans of the knee is a common disorder of unknown cause. It is thought that it may result from ischemia in a certain localized area of subchondral bone that is precipitated by infarction, trauma or other causes. The treatment for osteochondritis dissecans of the knee in children is conservative because the fragments are unstable. In adults too, the fragments are unstable, but can be excised when small and outside of the load-bearing area. When the fragments are bigger and in load-bearing areas, they 


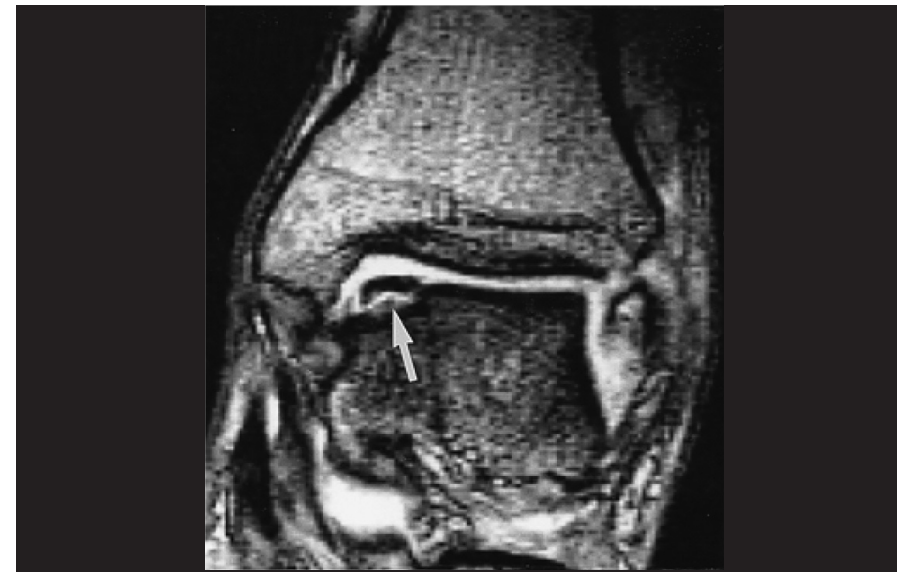

Figure 8 - Osteochondral lesion of the talus.

should be treated by means of perforation or curettage in association with fixation of the fragment, and also by means of homologous osteochondral grafts or arthroplasty (Figures 9 and 10).

In cases of patellar chondromalacia, the treatment depends on the degree of injury. If the lesion is less extensive and shallower, it can be treated conservatively. If it is deep, often with exposure of subchondral bone, it can be treated by means of curettage, perforation and autologous grafting. The surgical results are worse than when the femur or tibia is affected.

In cases of hip and knee osteoarthrosis, both conservative and surgical treatment options exist (Figures 11 and 12). The current arsenal of conservative treatment methods includes chondroprotective agents (hyaluronic acid, glucosamine and chondroitin), which have presented satisfactory results in all studies on humans, albeit with short follow-up duration. When conservative treatment fails, osteotomy, replacement arthroplasty or arthrodesis can be indicated.
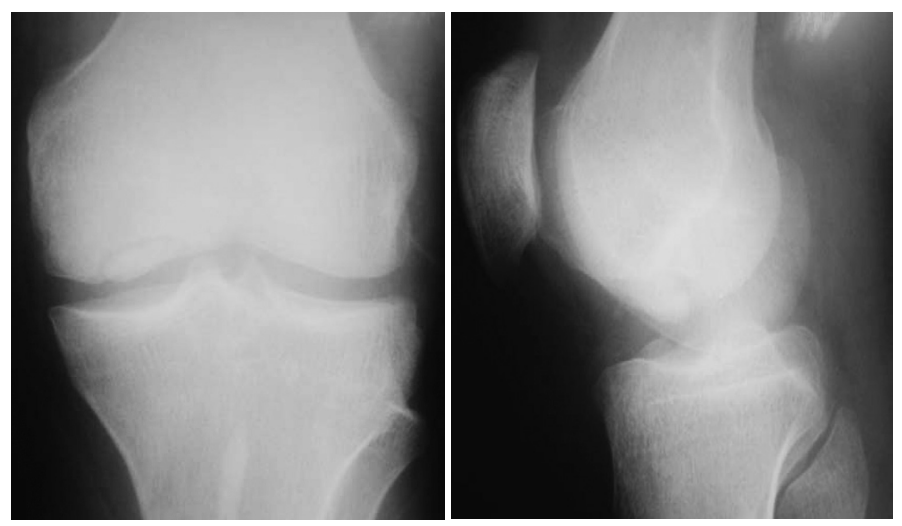

Figures 9 and 10 - AP and lateral radiographs on a patient with osteochondritis dissecans of the medial femoral condyle in a loadbearing area.

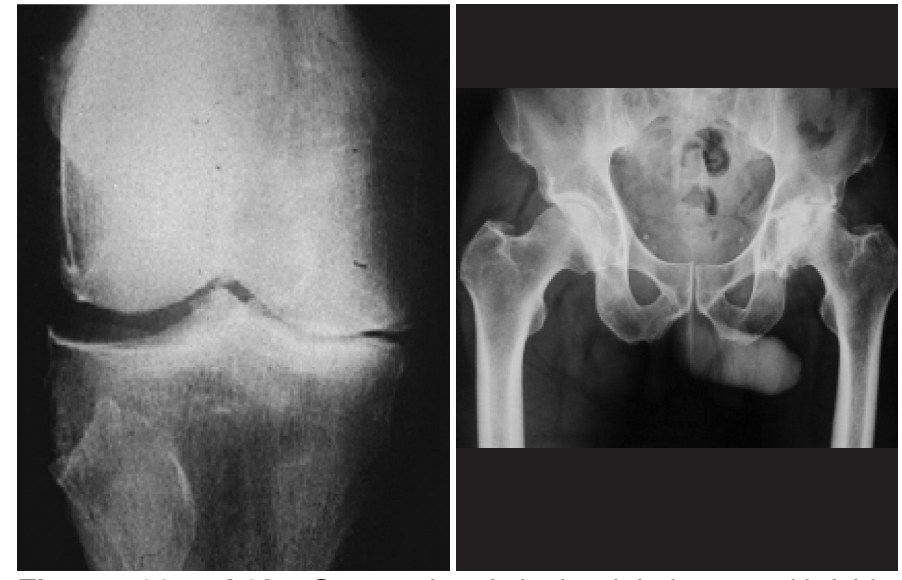

Figures 11 and 12 - Osteoarthrosis in the right knee and left hip.

Autologous and heterologous grafts have greater failure rates than seen in other joint cartilage diseases.

The importance of stem cells as a new method for treating chondral lesions is due to the fact that joint cartilage has little capacity for repair. The technique of transplanting cultures of autologous chondrocytes into chondral defects is restricted to small lesions in young individuals. On the other hand, recent studies have proven that mesenchymal progenitor cells may be able to repair larger defects, independent of age. The major problems are still the culturing, induction of differentiation and adherence at the lesion site ${ }^{(59-61)}$.

In addition to stem cells, growth factors are needed in order to determine the proliferation and differentiation in cartilaginous tissue, both during in vitro culturing and at the time of implantation. One of these factors is prolactin, which induces cell proliferation, proteoglycan synthesis and cell interaction, and inhibits the formation of type II collagen. Other factors that determine chondrogenesis include the insulin-like growth factor 1 (IGF-1) and the transformer growth factor beta 1 (TGF $\beta 1)^{(62,63)}$.

With this new therapeutic technique, the morbidity in the donor area can be diminished in cases of mosaic grafting (removal of small mosaics of cartilage from an area of lower loading to another with an osteochondral defect); the passage of pathogens and deterioration of allografts can be avoided; and revisions due to loosening or worm material in cases of joint prostheses can be avoided ${ }^{(64)}$.

Greater-impact studies on humans are needed in order to define the real purpose of stem cells in joint cartilaginous diseases. 


\section{BONE TISSUE}

In traumatology, one of the major complications is the condition of so-called pseudarthrosis. This word means false articulation and is used to denote nonunion of the fragments of a mild fracture that leads to formation of a pseudocapsule with synovium and synovial fluid.

Pseudarthrosis can be divided into two main types: hypertrophic or hypervascular and atrophic or avascular. The main cause of the first type is movement at the fracture focus and main cause of the second type is a lack of local biological conditions for bone consolidation (Figure 13).
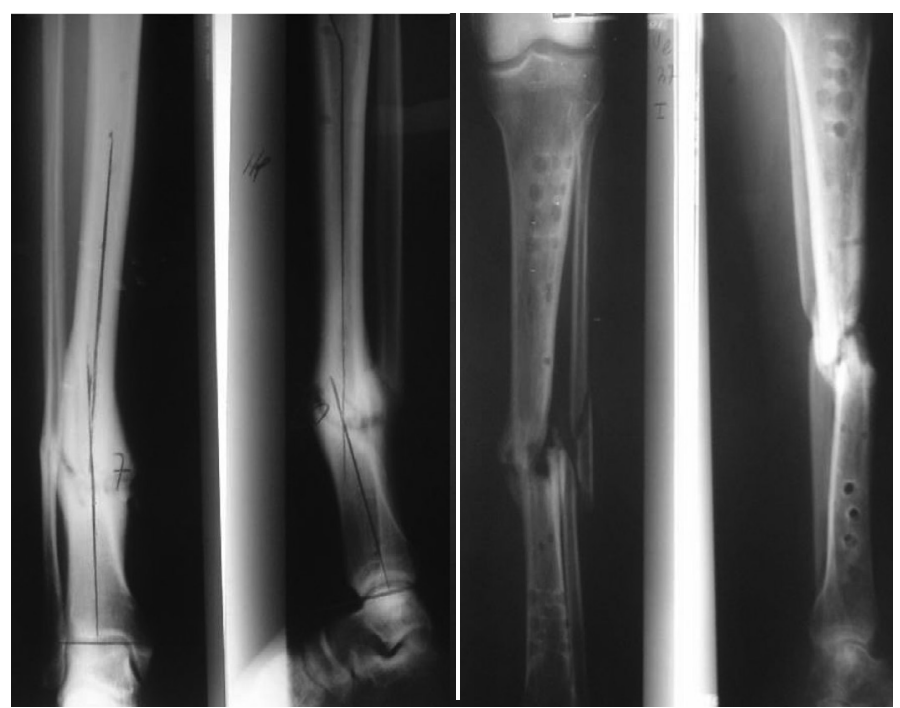

Figure 13 - Hypertrophic pseudarthrosis of bones of the right leg and atrophic pseudarthrosis of the left leg.

In hypertrophic pseudarthrosis, the treatment aims to improve the stability of the fracture, through plaster casts, orthoses, osteosynthesis or external fixators. The advantage of these last two is that as well as stabilizing the fracture, they can compress the focus.

Stem cells are applicable as a form of treatment in relation to the second type of pseudarthrosis, i.e. the atrophic type (Figures 13 and 14). Consolidation is known to consist of three phases: I-inflammation, in which infiltration of leukocytes occurs and causes chemotaxis of mesenchymal cells and fibroblasts, which become differentiated into osteoblasts; II-repair, in which a soft callus is formed (flaccid fibroblastic connective tissue) and then a hard callus (immature bone tissue); and III-remodeling, in which the mature

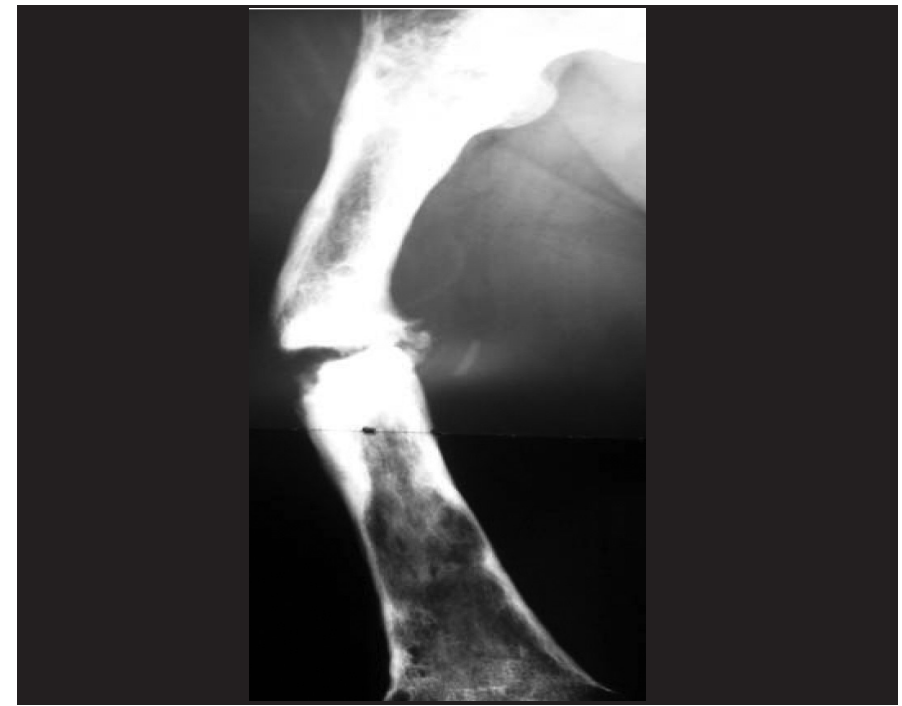

Figure 14 - Avascular pseudarthrosis of the femoral diaphysis.

bone tissue is formed. Thus, progenitor cells could have an influence in the first two phases ${ }^{(64)}$.

Physical methods such as ultrasound and electromagnetic pulses can be used as treatment variations for atrophic pseudarthrosis, although the results are doubtful. Studies with a higher level of evidence (randomized controlled clinical trials) with a longer follow-up are needed in order to reach definitive conclusions.

Autologous grafts (from the iliac, tibia or distal radius) or homologous grafts (bone from a tissue bank) can also be used. The great advantage of autologous grafts is their osteogenic, osteoconductive and osteoinductive capacity. Osteogenesis occurs because of the microenvironment that is formed with trophic factors. These cause recruitment of mesenchymal cells and fibroblasts, and their differentiation into bone tissue. Osteoinduction relates to specific proteins that cause local bone growth. Osteoconduction relates to the substrate or framework within which bone can be formed. Grafts from a bank and bone substitutes like hydroxyapatite only have osteoconductive capacity.

Bone morphogenetic protein (BMP) is another form of treatment for atrophic pseudarthrosis, with osteoinductive capacity.

One simple technique for local infiltration of totipotent cells is to use an aspirate from the bone marrow of the iliac. However, the low cellularity of this material makes the method questionable. Its action is perhaps due more to the presence of BMP than to the presence of totipotent cells ${ }^{(65)}$ 
For stem cell therapy to be successful, high cellularity in the collected material is needed, with adequate culturing to form bone lineage cells and trophic factors ${ }^{(63)}$.

Use of stem cells to form bone tissue gives rise to diminished morbidity in the bone graft donor area and avoids disease transmission through homologous $\operatorname{grafts}^{(64,65)}$.

There are very few studies on stem cells used for bone formation. An experimental study on rats showed that there was a benefit from using stem cells at osteotomy foci that were under treatment with relaxation using external fixators, thereby giving rise to improved local vascularization and faster consolidation, within one to two weeks ${ }^{(66)}$.

\section{DENSE CONNECTIVE TISSUE}

Ligaments and tendons are formed by true connective tissue of dense type. For this to occur, traction forces are needed. This tissue is mainly composed of fibroblasts and types I and III collagen fibers.

The anterior cruciate ligament (ACL) and medical collateral ligament (MCL) of the knee are the structures that are most often injured in sports practice, accounting for up to $90 \%$ of injured ligaments. The MCL is treated conservatively, but the ACL is preferentially treated by means of arthroscopic reconstructive surgery. Today, the options available for autologous grafting for the ACL consist mainly of the patellar, semitendinosus, gracilis and quadriceps tendons. Homologous grafts from the Achilles tendon form an alternative. The greatest criticism of these surgical procedures is the morbidity in the donor area. In such cases, stem cells would avoid this nuisance ${ }^{(64)}$.

There are studies demonstrating different degrees of regeneration of intra-articular tissue in affected knees, including ACL, meniscal or chondral lesions, after injections of stem cells into the joint. This provides a new therapeutic option for these joint lesions ${ }^{(67)}$ (Figure 15).

The Achilles tendon is one of the tendons most subjected to injury. The treatment can be conservative or surgical. The advantage of conservative treatment is that it avoids surgical complications like skin necrosis, infection or neurovascular lesions. The disadvantage is the lower resistance and consequently greater risk of renewed tearing. The inverse applies to surgical treatment. The surgical options consist of open repair using a Krackow suture, percutaneous repair using an " $\mathrm{x}$ " suture and various types of tendon reinforcement (long flexor of the hallux, short plantar ligament, short fibular ligament and aponeurosis of the sural triceps). Stem cells have become a new technique that in the future may be applied to cases of tendon failure without increasing the duration of surgery and without loss of function of the transferred tendons (Figure 16).

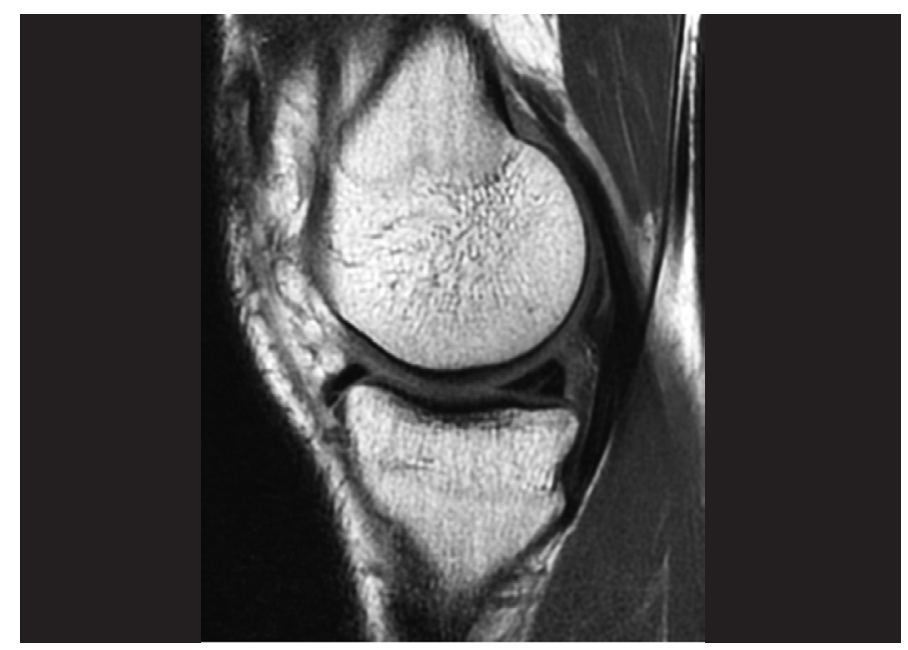

Figure 15 - Lesion of the medial meniscus.

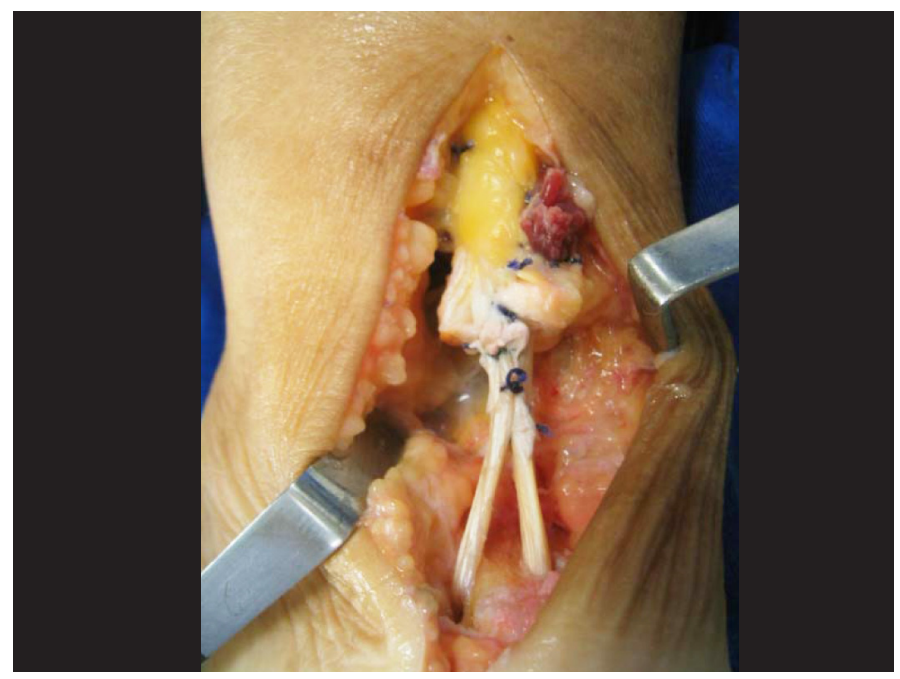

Figure 16 - Intraoperative photo after resection of the torn diseased tendon, with reinforcement using the long flexor tendon of the hallux.

\section{FINAL REMARKS}

There are many studies on the topic of stem cells in the literature, both in the form of experimental studies and in the form of clinical trials. This topic appears to be one of the most promising fields within medicine, capable of providing solutions for diseases that so far have not had any solutions. 


\section{REFERENCES}

1. Forsberg EC, Bhattacharya D, Weissman IL. Hematopoietic stem cells: expression profiling and beyond. Stem Cell Rev. 2006;2(1):23-30.

2. Li Y, Chi XC, Li XX, Xu JC. Multipotency of human neural stem cells from fetal striatum. Neuroreport. 2008;19(17):1679-83.

3. de Barros Filho TE, de Oliveira RP, Tsanaclis AM, de Barros EM, Cristante AF, Palma RM, et al. An experimental model for the transplantation of fetal central nervous system cells to the injured spinal cord in rats. Ver Hosp Clin Fac Med Sao Paulo. 2002;57(6):257-64

4. Braughler JM, Hall ED. Current application of "high-dose" steroid therapy for CNS injury. A pharmacological perspective. J Neurosurg. 1985;62(6):806-10.

5. Breasted JH. The Edwin Smith surgical papyrus. Chicago: University of Chicago Press; 1930.

6. Behrmann DL, Bresnahan JC, Beattie MS. Modeling of acute spinal cord injury in the rat: neuroprotection and enhanced recovery with methylprednisolone, U-74006F and YM-14673. Exp Neurol. 1994;126(1):61-75.

7. Ducker TB, Hamit HF. Experimental treatments of acute spinal cord injury. J Neurosurg. 1969;30(6):693-7.

8. Faden Al, Salzman S. Pharmacological strategies in CNS trauma. Trends Pharmacol Sci. 1992;13(1):29-35

9. Tator $\mathrm{CH}$, Rowed DW. Current concepts in the immediate management of acute spinal cord injuries. Can Med Assoc J. 1979;121(11):1453-64.

10. Young W, DeCrescito V, Flamm ES, Blight AR, Gruner JA. Pharmacological therapy of acute spinal cord injury: studies of high dose methylprednisolone and naloxone. Clin Neurosurg. 1988;34:675-97.

11. Allen AR. Remarkes on histopathological changes in spinal cord due to impact: an experimental study. J Nerv Ment Dis. 1914;41:141-7.

12. Allen AR. Surgery of experimental lesions of spinal cord equivalent to crush injury of fracture dislocation. Preliminary report. J Am Med Assoc. 1911;57:878-80.

13. Anderson DK, Means ED, Waters TR, Spears CJ. Spinal cord energy metabolism following compression trauma to the feline spinal cord. J Neurosurg 1980;53(3):375-80

14. Balentine JD. Hypotheses in spinal cord trauma research. In: Becker DP, Povlishock J T, editors. Central nervous system trauma status report. Bethesda: $\mathrm{NIH}$; 1985. p. 455-61.

15. Balentine JD. Pathology of experimental spinal cord trauma. II. Ultrastructure of axons and myelin. Lab Invest. 1978;39(3):254-66.

16. Demopoulos HB, Flamm ES, Pietronigro DD, Seligman ML. The free radical pathology and the microcirculation in the major central nervous system disorders. Acta Physiol Scand Suppl. 1980;492:91-119.

17. Dohrmann GJ, Wagner FC, Bucy PC. The microvasculature in transitory traumatic paraplegia. An electron microsopic study in the monkey. J Neurosurg. 1971;35:263-71.

18. Goodkin R, Campbell JB. Sequencial pathological changes in spinal cord injury: a preliminary report. Surg Forum. 1996;20:430-2

19. Spiller WG. A microscopic study of the spinal cord in two cases of Pott's disease. Bulletin of the Johns Hopkins Hosp. 1898;9:125-33.

20. Noble LJ, Wrathall JR. Distribution and time course of protein extravasation in the rat spinal cord after contusive injury. Brain Res. 1989;482(1):57-66.

21. Wagner FC Jr, VanGilder JC, Dohrmann GJ. Pathological changes from acute to chronic in experimental spinal cord trauma. J Neurosurg. 1978;48(1):92-8.

22. Seshi B, Kumar S, Sellers D. Human bone marrow stromal cell: coexpression of markers specific for multiple mesenchymal cell lineages. Blood Cells Mol Dis. 2000;26(3):234-46.

23. Ducker TB, Salcman M, Perot PL Jr, Ballantine D. Experimental spinal cord trauma, I: Correlation of blood flow, tissue oxygen and neurologic status in the dog. Surg Neurol. 1978;10(1):60-3.

24. Dusart I, Schwab ME. Secondary cell death and the inflammatory reaction after dorsal hemisection of the rat spinal cord. Eur J Neurosci. 1994;6(5):712-24

25. Green BA, Wagner FC Jr. Evolution of edema in the acutely injured spinal cord: a fluorescence microscopic study. Surg Neurol. 1973;1(2):98-101.

26. Herrick MK, Mills PE Jr. Infarction of spinal cord. Two cases of selective gray matter involvement secondary to asymptomatic aortic disease. Arch Neurol. 1971;24(3):228-41.

27. Holtz A, Nyström B, Gerdin B. Spinal cord blood flow measured by 14C-iodoantipyrine autoradiography during and after graded spinal cord compression in rats. Surg Neurol. 1989;31(5):350-60.
28. Janssen L, Hansebout RR. Pathogenesis of spinal cord injury and newer treatments. A review. Spine (Phila Pa 1976). 1989;14(1):23-32.

29. Rivlin AS, Tator $\mathrm{CH}$. Regional spinal cord blood flow in rats after severe cord trauma. J Neurosurg. 1978;49(6):844-53.

30. Tator $\mathrm{CH}$, Fehlings MG. Review of the secondary injury theory of acute spinal cord trauma with emphasis on vascular mechanisms. J Neurosurg. 1991;75(1):15-26.

31. Faden Al, Ellison JA, Noble LJ. Effects of competitive and non-competitive NMDA receptor antagonists in spinal cord injury. Eur J Pharmacol. 1990;175(2):165-74.

32. Faden AI, Jacobs TP, Mougey E, Holaday JW. Endorphins in experimental spinal injury: therapeutic effect of naloxone. Ann Neurol. 1981;10(4):326-32.

33. Luer MS, Rhoney DH, Hughes M, Hatton J. New pharmacologic strategies for acute neuronal injury. Pharmacotherapy. 1996;16(5):830-48.

34. Young W, Flamm ES, Demopoulos HB, Tomasula JJ, DeCrescito V. Effect of naloxone on posttraumatic ischemia in experimental spinal contusion. J Neurosurg. 1981;55(2):209-19.

35. Anderson DK, Means ED, Waters TR, Green ES. Microvascular perfusion and metabolism in injured spinal cord after methylprednisolone treatment. J Neurosurg. 1982;56(1):106-13

36. Bracken MB. Pharmacological treatment of acute spinal cord injury: current status and future projects. J Emerg Med. 1993;11(Suppl 1):43-8.

37. Braughler JM, Hall ED. Pharmacokinetics of methylprednisolone in cat plasma and spinal cord following a single intravenous dose of the sodium succinate ester. Drug Metab Dispos. 1982;10(5):551-2.

38. Braughler JM, Hall ED. Lactate and pyruvate metabolism in injured cat spinal cord before and after a single large intravenous dose of methylprednisolone. J Neurosurg. 1983;59(2):256-61.

39. De Ley $G$, Leybaert L. Effect of flunarizine and methylprednisolone on functional recovery after experimental spinal injury. J Neurotrauma. 1993;10(1):25-35.

40. Hall ED, Braughler JM. Acute effects of intravenous glucocorticoid pretreatment on the in vitro peroxidation of cat spinal cord tissue. Exp Neurol. 1981;73(1):321-4.

41. Hall ED. The effects of glucocorticoid and nonglucocorticoid steroids on acute neuronal degeneration. In: Sell FJ, editor. Advances in neurology. New York: Raven; 1993. p. 241-8.

42. Hall ED, Braughler JM. Effects of intravenous methylprednisolone on spinal cord lipid peroxidation and $\mathrm{Na}++\mathrm{K}+$ )-ATPase activity. Dose-response analysis during 1st hour after contusion injury in the cat. J Neurosurg. 1982;57(2):247-53.

43. Hall ED, Wolf DL, Braughler JM. Effects of a single large dose of methylprednisolone sodium succinate on experimental posttraumatic spinal cord ischemia. Dose-response and time-action analysis. J Neurosurg. 1984;61(1):124-30.

44. Hall ED, McCall JM, Chase RL, Yonkers PA, Braughler JM. A nonglucocorticoid steroid analog of methylprednisolone duplicates its high-dose pharmacology in models of central nervous system trauma and neuronal membrane damage. J Pharmacol Exp Ther. 1987;242(1):137-42.

45. Hall ED, Yonkers PA, Andrus PK, Cox JW, Anderson DK. Biochemistry and pharmacology of lipid antioxidants in acute brain and spinal cord injury. J Neurotrauma. 1992;9(Suppl 2):S425-42.

46. Means ED, Anderson DK, Waters TR, Kalaf L. Effect of methylprednisolone in compression trauma to the feline spinal cord. J Neurosurg. 1981;55(2):200-8.

47. Richardson HD, Nakamaura S. An electron microscopic study of spinal cord edema and the effect of treatment with steroids, mannitol, and hypothermia. Proc Veterans Adm Spinal Cord Inj Conf. 1971;18:10-6.

48. Anderson DK, Braughler JM, Hall ED, Waters TR, McCall JM, Means ED. Effects of treatment with U-74006F on neurological outcome following experimental spinal cord injury. J Neurosurg. 1988;69(4):562-7.

49. Hall ED. Effects of the 21-aminosteroid U74006F on posttraumatic spinal cord ischemia in cats. J Neurosurg. 1988;68(3):462-5.

50. Cuello AC, Garofalo L, Kenigsberg RL, Maysinger D. Gangliosides potentiate in vivo and in vitro effects of nerve growth factor on central cholinergic neurons. Proc Natl Acad Sci U S A. 1989;86(6):2056-60.

51. Geisler FH, Dorsey FC, Coleman WP. Recovery of motor function after spinalcord injury--a randomized, placebo-controlled trial with GM-1 ganglioside. N Engl J Med. 1991; 324(26):1829-38.

52. Geisler FH, Dorsey FC, Coleman WP. Past and current clinical studies with GM-1 ganglioside in acute spinal cord injury. Ann Emerg Med. 1993;22(6):1041-7. 
53. Gorio A. Gangliosides as a possible treatment affecting neuronal repair processes. In: Waxman SG, editor. Advances in neurology: functional recovery in neurological disease. New York: Raven; 1988. p. 523-30.

54. Karpiak SE, Wakade CG, Tagliavia A, Mahadik SP. Temporal changes in edema $\mathrm{Na}+, \mathrm{K}+$, and $\mathrm{Ca}++$ in focal cortical stroke: GM1 ganglioside reduces ischemic injury. J Neurosci Res. 1991;30(3):512-20.

55. Mahadik SP, Hawver DB, Hungund BL, Li YS, Karpiak SE. GM1 ganglioside treatment after global ischemia protects changes in membrane fatty acids and properties of $\mathrm{Na}+, \mathrm{K}+-\mathrm{ATP}$ ase and Mg2+-ATPase. J Neurosci Res. 1989;24(3):402-12.

56. Walker JB, Harris M. GM-1 ganglioside administration combined with physical therapy restores ambulation in humans with chronic spinal cord injury. Neurosci Lett. 1993;161(2):174-8.

57 . Young W. Recovery mechanisms in spinal cord injury: implicatíons for regenerative therapy. In Seil AJ. Neural regeneration and transplantation. New York: Alan Liss; 1995. p. 157-9.

58. Nagase T, Muneta T, Ju YJ, Hara K, Morito T, Koga H, et al. Analysis of the chondrogenic potential of human synovial stem cells according to harvest site and culture parameters in knees with medial compartment osteoarthritis. Arthritis Rheum. 2008;58(5):1389-98.

59. Cristante AF, Barros-Filho TE, Tatsui N, Mendrone A, Caldas JG, Camargo $A$, et al. Stem cells in the treatment of chronic spinal cord injury: evaluation of somatosensitive evoked potentials in 39 patients. Spinal Cord 2009;47(10):733-8.
60. Corvol MT. [Cell therapy and its clinical applications. Cartilage cell therapy, present and future]. J Soc Biol. 2001;195(1):79-82.

61. Barry FP. Mesenchymal stem cell therapy in joint disease. Novartis Found Symp. 2003.

62. Ogueta S, Muñoz J, Obregon E, Delgado-Baeza E, García-Ruiz JP. Prolactin is a component of the human synovial liquid and modulates the growth and chondrogenic differentiation of bone marrow-derived mesenchymal stem cells. Mol Cell Endocrinol. 2002;190(1-2):51-63.

63. Fukumoto T, Sperling JW, Sanyal A, Fitzsimmons JS, Reinholz GG, Conover $\mathrm{CA}$, et al. Combined effects of insulin-like growth factor-1 and transforming growth factor-beta1 on periosteal mesenchymal cells during chondrogenesis in vitro. Osteoarthritis Cartilage. 2003;11(1):55-64.

64. Rahaman MN, Mao JJ. Stem cell-based composite tissue constructs for regenerative medicine. Biotechnol Bioeng. 2005;91(3):261-84.

65. Hernigou P, Beaujean F. [Bone marrow in patients with pseudarthrosis. A study of progenitor cells by in vitro cloning]. Rev Chir Orthop Reparatrice Appar Mot. 1997;83(1):33-40.

66. Cetrulo CL Jr, Knox KR, Brown DJ, Ashinoff RL, Dobryansky M, Ceradini DJ, et al. Stem cells and distraction osteogenesis: endothelial progenitor cells home to the ischemic generate in activation and consolidation. Plast Reconstr Surg. 2005;116(4):1053-64.

67. Agung M, Ochi M, Yanada S, Adachi N, Izuta Y, Yamasaki T, et al. Mobilization of bone marrow-derived mesenchymal stem cells into the injured tissues after intraarticular injection and their contribution to tissue regeneration. Knee Surg Sports Traumatol Arthrosc. 2006;14(12):1307-14. 